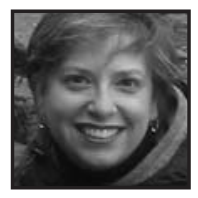

\title{
Focusing on the Earth: Using Photography and Photo Elicitation as Instruments to Engage Children as Coresearchers in a Community Garden
}

Ann Grugel, University of Wisconsin Madison

\section{ABSTRACT}

In this article, the use of photographs and photo elicitation are used as models for engaging elementary children in collaborative research. Based on ethnographic research conducted in a community garden, the author illustrates how digital cameras act as a symbolic device that allow children to "pivot" (Vygotsky, 1978) into the world of researcher within the boundaries of a natured setting. Using photonarratives constructed by three children which document their outside, social experiences in the garden, the author suggests that their still images and accompanying narratives expose complex interrelationships between empathy, exploration and the natural environment.
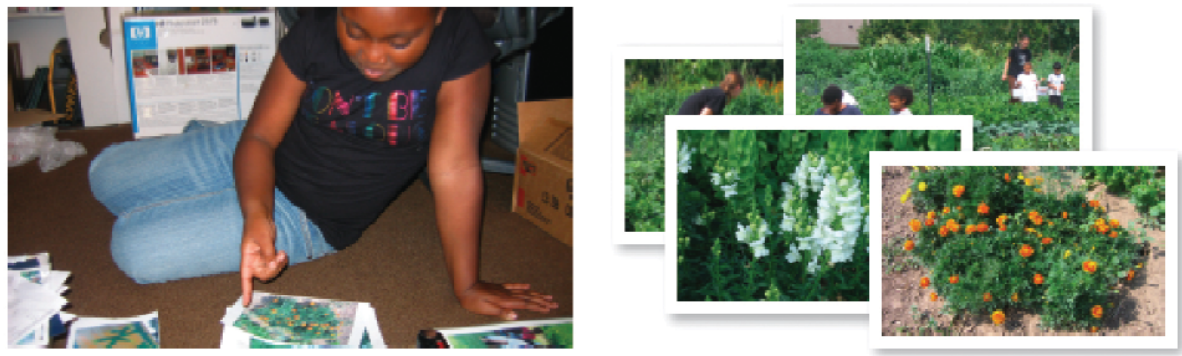

Fig. 1: Pictures from a children's community garden 
like this picture,"Tamika declared, as she pointed to one of the many digital photographs strewn across the black carpeting (note: individual and place names in this article are pseudonyms). She had taken several hundred pictures while working in a children's community garden during the summer of 2007. Now, sitting on the office floor in the community center, amidst papers and old computer parts, I watched as Tamika, a nine-year-old girl, separated these photographs into two piles: those which illustrated her role as a gardener and those which did not. To casual observers it might appear as if she and I, as friends, were creating a scrapbook-a representation of time spent in the children's garden. When in fact, we, as research partners, were using these still images to discuss her natured experiences. During the second of three photo-elicitation interview sessions, I asked her to tell me about one of the pictures that illustrated part of her story as a gardener. She picked up this photo and explained:

This is a picture of flowers, orange and yellow flowers and it has lettuce in the background and some is all the way yellow and all the rest are yellow and orange together. Some of them are still growing but some of them sprouted. And on the ground is weeds around it, but we pulled 'em already after I took the picture. We got a lot of weeds in the middle of the flowers. I like the lettuce. I really love the flowers and I like to see the lettuce. I wanted to take a picture of the weeds before we picked them. Weeds are green and look pretty.

There are flowers, but they is white and they are kinda up and some is together. You can see a little green in them. Some on the top are going to sprout and some have not sprouted yet. And they look so pretty with all the green around it. These flowers are red and have weeds around them too. They have a stick in them. I really like the red flowers. They are so, so pretty. And I just love them.

In my story, the plants go first. The people are important to me, but the plants should go first. I really love the plants. People mean stuff to me, but plants mean more to me because we are plants ourselves. We are plants too! (Photo elicitation interview, September 8, 2007)

Over the course of four summers, Tamika and I have become friends. From May through September, we labor together to care for a small area within a community children's garden. She, along with other elementary-aged children from the neighborhood community center's summer camp program, join a group of adult volunteers twice a week to grow vegetables and nurture relationships with each other and the earth. Over time, I have learned that Tamika enjoys coming to this place to plant seedlings, pull weeds, water and care for the living creatures, especially the flowers. 
However, it was not until after a series of photo elicitation interviews that I realized the deep connection between her self and the natural environment. Through her photographs and our conversations, Tamika was exploring her personal self as linked within the broader context of the natural world. She in fact was constructing an ecological identity.

I begin with Tamika's story as it illustrates the benefits and insights that I was hoping to discover in my photo-elicitation study. First, by providing Tamika and three other gardeners with access to a digital camera they were able to visually document their experiences in a community garden. During the photo elicitation interviews, these young children were able to articulate aspects of their ecological selves that might have been eclipsed if I had only used field notes and structured interview questions. Second, photo elicitation helped me unearth and explore the dominant social and environmental practices that support the development of a child's ecological identity within the social context of a community garden. Furthermore, I would not have been able to examine a child's relationship with the natural world by just observing children engaged in outdoor activities. I will briefly explain this here, as it will illuminate the purpose of the study.

For the last twenty years, I have watched children retreat from neighborhood landscapes. City parks, once used by children as terrains for exploration and adventure, are often "signed out" for organized activities rather than free, imaginative play. Fewer and fewer swing-sets and sandboxes dot the backyards of suburbia, and more and more children return home from school to sit inside, engaged with one or more electronic devices. Even at school, children race in from recess to check the status of their friends on Facebook and MySpace. As a casual observer of this childhood migration, I have begun to fear that in just a short time we will witness what Louv (2005) refers to as, The Last Child in the Wilderness. After reading his book, I began to wonder if Louv's premise supported my own concerns regarding identity development; in that, if natured experiences are critical to the development of self, how are our natured experiences and related narratives critical to our identity development? How can we understand and experience the intersecting relationships between human and ecological systems without prior experience being in nature? Finally, how might educators engage elementary-aged children in an educational design process that encourages the exploration of self in nature?

I have volunteered in a children's community garden for several summers and decided to explore these thoughts within the context of this space. During the summer of 2007, I asked three elementary-aged children, participating in the 
community children's garden, to document their experiences within this garden space using digital cameras. These digital images, utilized during multiple photo-elicitation sessions, aided each participant in the construction of a photo narrative that illustrated his or her garden experiences. Children in this study used their photographs to visually document relationships that connected them with the subculture of the garden. Pictured through their camera lens, they documented their natured experiences, their understanding of what it means to act as a member of a garden community, and the multiple systems that operate within it. Through this visual framing, it becomes possible for me as a researcher and educator to "see" how these particular children understand themselves as knowers of natural events, and as actors who shape an ecological system. This article focuses on the use of still photography (Collier, 2001; Harper, 1994; Tucker \& Dempsey, 1991) as a method of collecting visual data and eliciting verbal information from two of these elementary-aged children regarding their experiences in nature, as they become community gardeners.

\section{Situating My Study}

\section{The Garden as an "Ecological Carnival"}

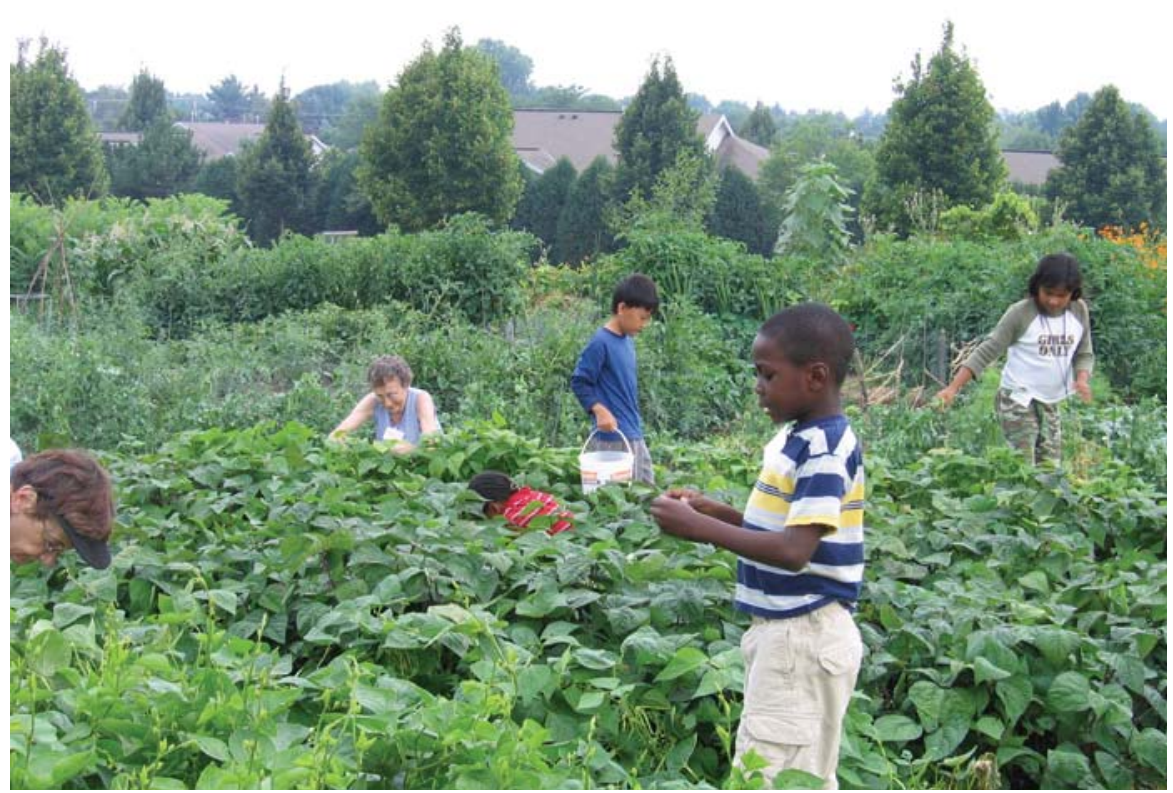

Fig. 2: Community gardeners in action 
It is a sweltering day in mid-August. The sun is high and unrelenting as it bears down on the land and the twenty-three community gardeners who have gathered to harvest ripened vegetables. Sweat drips from their bodies as they pick tomatoes, tomatillos, cilantro, patty pan, Thai chilies, Trail of Tear beans, green zucchini and much more. These gardeners work in teams of two-one adult, over the age of fifty and one child, under the age of ten. Working side by side, these "garden buddies" pick for the last time this season. Today, they do what they have done twice a week all summer: water, explore, play, weed, harvest and cook fresh produce together. When they planted the seeds and starters in May, many of them didn't know each other, at least not very well. As they went into the garden those first few times it was quiet, except for the rhythmic sounds of shovels and children's trowels pecking at the earth. While they planted seeds in rows, children didn't talk. Instead, their focus was on carefully measuring the distance between the seeds using the lengths of their fingers or feet.

Now, in mid-August, it's different. Voices ring out over the overgrown vegetables. Gardeners call out to one another to come and see oversized tomatoes or to witness the number of potatoes being released from the ground. As these garden buddies tend, they engage each other in summer remembrances. As I walk from section to section, I overhear stories of gigantic bugs, green pumpkins, prickly straw, hobbit adventures, killing weeds and bare feet. I leave the garden to sit with Sarah, a ten-year-old girl, who is writing the last entry in her garden journal:

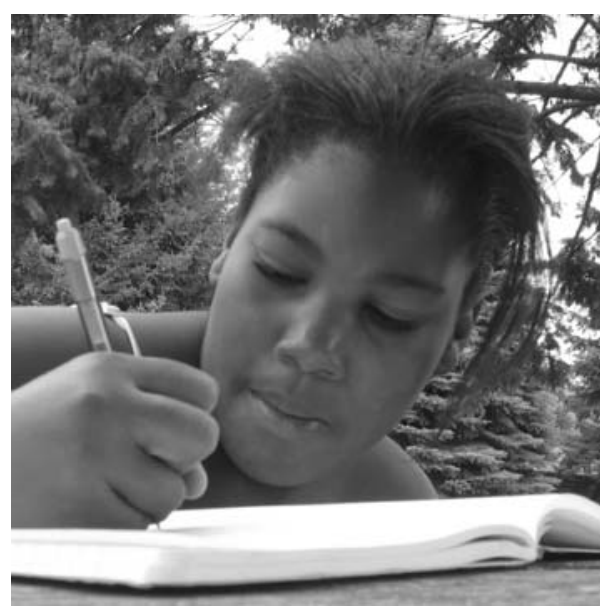

Fig. 3: Garden journal entry

I'm going to miss being here because I like to water and plant seeds. When I look into the garden I see yellow, green and red Swiss Chard, kale, hay, potatoes, flowers, squash and mulch. My group watered flowers and all kinds of things this summer. I like to water and plant seeds. I also like to pick pumpkins and pick tomatoes. I'm going to miss cooking because we cooked vegetables. We use what we planted to make salads, stir fry, zucchini bread and pizza. We have all worked hard in the garden. I will miss my buddy who been helping in the garden to. The garden is a place that teaches about peace and respect. (Journal entry, August 16, 2007) 
She put down her pen. I asked if she had anything to add. After a few thought filled seconds, she looked up at me and said, "I will miss me in the garden." Then, she closed her journal, got up from the picnic table and walked down into the garden. As I watched her return to the garden for the last time, I wondered: Who is this "me" that Sarah will miss? (Field notes, August 16, 2007)

After all the gardeners left that day, I wandered alone among the vegetables to think about Sarah's words. Is she going to miss physically being in the garden, or will she miss some inner self that exists in this social environment? I wondered how Sarah defines her garden self. How does she consider her garden self different from her other selves? And, why does she feel she needs to leave this "me" in the garden? As I pick my way through the various beans, I imagined Bakhtin, sitting beneath the shade tree filling pages of a notebook with his observations and analysis of Sarah's way of "authoring" her self. I wondered how Bakhtin might write about Sarah's statement of identity. How would he consider gardener stories, like Sarah's, as texts that reveal the social relationships that exist within a community garden? Would he write about her garden "self" as "outsideness" or as her ecological authorial stance? Finally, how would he posit the existence of the human-nature relationship as dialogic? Or would he?

During this imagined Bakhtinian exchange, I contemplated the existence of a human-nature dialogic relationship within the context of the garden. To do so, I started by associating the garden with Bakhtin's (1981) concept of collectivity within carnival. At carnival time, or in this case garden time, a unique sense of time and place allows us to feel part of a collective, part of an ecosystem. Like Sarah and Tamika, we cease to be ourselves and become part of a community. Like carnival, in the garden we can "try on" on ways of acting with others (i.e., both human and nonhuman entities) in the environment. Therefore, I wondered, in what ways are our outdoor experiences with the natural world and the stories we author about being in nature critical to our identity development? And, how does Sarah's ecological worldview, reflected in her journal and her photographs, play a role in developing an aspect of her "self" that Thomashow (1996) refers to as an ecological identity?

This study of connections between self and the natural environment emerged from my involvement in this community children's garden. When I began to ask children who would like to volunteer to be part of a research project, I had already developed relationships with them. I took photographs of them and spent time observing their actions and listening to their conversations that hovered over the landscape. Through my ethnographic fieldwork, I realized that many of the children 
participating in the community garden had relationships with nonhuman beings: plants, rabbits, tomato worms, and so forth. I wanted to understand how these nonhuman-human relationships developed and impacted these children's personal experiences in the garden. I quickly realized that my observations and structured interview questions alone were not enough. I needed to engage them as collaborative partners in this project. With parental permission, I asked three children to use a digital camera to document their experiences as a gardener in this place. I also turned to the literature on ecological identity development to help me understand how people develop an ecological understanding and a sense that the self is an element within a much larger system. Very quickly, I discovered a gap in the literature. To date, little environmental scholarship has been conducted with regard to eco-identity development in adults, and even less attention has been paid to children.

\section{Conceptual Framework}

Ecological identity, or eco-identity, refers to different ways people construe themselves in relation to the natural world - a nonhuman element-as manifested in their personalities, values, actions, and senses of self. "It includes a person's connection to the earth, perception of the ecosystem, and direct experience with nature" (Thomashow, 1996, p. 3). Environmental educators agree that our ecological identities, rooted in early childhood, develop over time through our natured experiences (Gruenewald, 2003, 2005; Haas \& Nachtigal, 1998; Orr, 1992; Sobel, 1996, 2008; Theobald, 1997; Thomashow, 1996). Walking through the woods or a park, observing the life cycles of squirrels or the growing season of a birch tree provides children with an opportunity to explore and develop a foundation and an understanding of their personal relationship with multiple ecosystems. Unfortunately, more and more children today spend time inside and less time in natural surroundings. In fact, only $6 \%$ of all children play outside on their own, and there has been a 31\% decrease in bike riding since 1995 (Louv, 2005). This migration indoors is the beginning of a "denatured" childhood (Louv, 2005). Like Thomashow and Orr, who believe that ecological identity work is paramount to our planet's sustainability, Louv asserts that natured experiences are necessary for the development of the ecological self, which is critical for the recovery of the planet.

Sobel (1996), in his ground breaking essay, "Beyond Ecophobia: Reclaiming the Heart in Nature Education," supports Louv's assertion and argues that educators need to provide opportunities for children "to bond with the natural world, to learn 
to love it and feel comfortable in it, before being asked to heal its wounds" (p. 10). Children need to see themselves as actors and participants working within their local ecosystem, not as individuals attempting to control the planet. In this essay, Sobel suggests a taxonomy of eco-identity development that should be of concern to parents and educators. He argues that a person's ecological identity develops during three life stages: early childhood (ages 4-7), characterized by empathy toward animals; elementary (ages 8-11), described as a time when children look for opportunities to explore beyond their own personal space into the neighborhood or into the natural world; and early adolescence (ages 12-15) when children develop concerns for ecological issues.

\section{DAVID SOBEL'S TAXONOMY OF ECOLOGICAL IDENTITY}

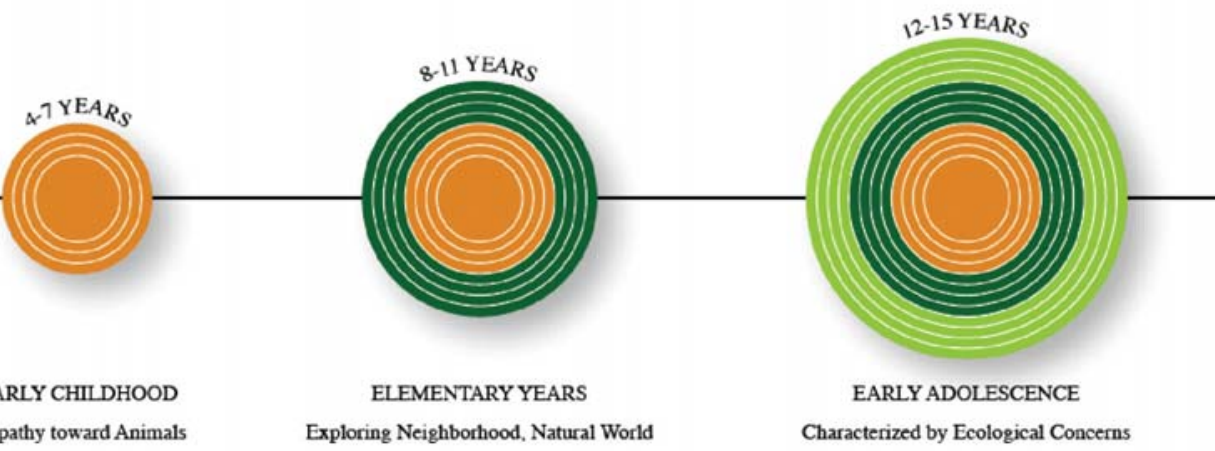

Fig. 4: Sobel's taxonomy of ecological identity

Although he states that these stages are linear, they should be considered flexible, and that environmental education should differ during each period.

Cobb, author of The Ecology of Imagination in Childhood, believes that the horizons of mind and nature should be united in what Hutchinson calls "the ecological theater" (Shepard, 1986). Like Sobel, Cobb considers the years of middle childhood, from six to eleven, to be the time when children are expanding their surroundings and moving from self to the natural environment. A child's play in the landscape, albeit a garden, backyard or alley, is the experience she says, that "is the prelude to loving the universe." These outdoor, exploratory activities of childhood are, she concludes, "the universal link between mind and nature" (Cobb, 1977, p. 39). Cobb points out that "the power of standing, moving, playing, molding, or just being in the world around him is part of the child's universal aesthetic logic in nature's formative process" (p. 39). It is during this time of exploration that children learn that paying attention involves our capacity for self-compassion. 
For an educator, the starting point is the child. A child's need for joy, safety, play, and the opportunity to explore his or her world concerns all educators, not just those involved with environmental education. The child's "ecological sense of continuity with nature" is not mystical but is "basically aesthetic and infused with the joy in the power to know and to be" (Cobb, 1977, p. 23). Childhood is the "point of intersection between biology and cosmology, where the structuring of our worldviews and our philosophies of human purpose takes place. In other words, our minds are rooted as much in the ecology in which our childhood is lived as in our ("over emphasized") animal instincts" (Cobb, 1977, p. 101). For Cobb, exploration and empathy are interconnected and dependent on each other rather than separate stages of ecological development.

\section{Autodriven Photo Elicitation}

\section{Methodology}

Before beginning this study, I had a number of questions and concerns. How could I generate questions about the human-nonhuman dialogic that young children would understand? How well would children remember and articulate what happened to them in the garden over the course of the summer? And, how could I limit the power dynamic of an adult gardener interviewing a child gardener? As I read through literature, searching for a method that would capture the natured experiences of these three children, and alleviate some of my concerns, I began to examine the possibility of using photo elicitation as a methodology.

Photo elicitation is an interview technique that involves using still photographs with research participants to assist them in reflecting upon past experiences (Harper, 1994; Tucker \& Dempsey, 1991). One of the challenges, as an ethnographer, working with children is developing a series of interview questions that reflects a child's experience in the field. Interview questions, initially generated from my own interests and queries, may or may not elicit responses from the interviewees as they are so young. My concern was that the children may not understand the question. Therefore, the responses given using a structured interview protocol may not reflect the actual, real world experience of the individual child. Rather, their reactions might mirror my own personal attitudes and experiences. For those of us investigating the world and lives of elementary-aged children, crafting relevant questions is especially difficult, and in many situations requires us to consider alternative interview meth- 
ods. Photo elicitation, as an interview protocol, worked well with these children. They decided what they wanted to say about the image rather than answering a series of structured interview questions about the photograph. During the interview, the photographs and the child's narrative guided our conversation rather than my predetermined questions.

This photo elicitation interview (PEI) technique operates with the "express aim of exploring participants' values, beliefs, attitudes and meanings in order to trigger memories, or to explore group dynamics or systems" (Prosser, 1998, p. 124). Using photographs stimulated the children's memory by providing them with tangible images they had taken only weeks before. Using their own photographs lessened feelings of angst as we focused on their photographs rather than a series of questions about their experiences. These photographs offered the children the opportunity to "soak in a place" and to "return to that place to ponder the visible substrate of his (her) own personality" (Shepard, 1996, p. 106). These photographs, socially constructed representations captured by the photographer, offered rich descriptive images that helped us, together, make sense of their subjective experiences (Ziller, 1990). Images, like those presented here, are representations that have visual meaning and offer a way of understanding how these children make meaning of their experience, and illustrate what influenced their actions and behaviors within the context of the garden.

According to Taylor (2002), using photographs "offers more than just the historical rendering of the setting and its participants. They often reveal unconscious beliefs behind the picture-taking process itself" (p. 123). In other words, the photograph can reveal the reasons behind the image: why the photographer chose that particular scene or subject; how the image affirms or challenges the thinking process and worldview of the photographer. For the purposes of this study, these photographs and their corresponding narratives reveal the intersections between exploration, empathy and ecological awareness.

Image as a form of text can be read. Photography and language are interdependent mediums for expression that have the potential to assist each other in making meaning of an experience (Taylor, 2002). "When descriptions and interpretations are generated for what is seen, language provides a 'frame' for the visual experience. Language then provides ways of assigning meaning to what we encounter visually, and it enables us to extend and enhance our interpretations of what we see" (Weade \& Ernst, 1990, p. 133). Similarly, photographs provide a frame for language, a place in which to focus the meaning-making process, and a catalyst that can extend and 
enhance the interpretation of what the participants believe about the subject under study (p. 127). The photographs in this study are not merely being interpreted by participants, but have the potential to promote a deeper understanding of the underlying values and assumptions about the environment, and contribute to the development of new understandings of the self. In this case, the eco-self.

Photo elicitation is not only a collaborative method between language and image, but it is also a model for collaborative research in that, as the researcher, I become the listener as the participant tells the story behind the image. There are a variety of different approaches to setting up and conducting PEls. Even before the interview, the researcher must decide who will take the photographs to be used during the interview process, who will organize and arrange the images, and how they will use the still photographs to elicit participant discussion throughout the unstructured interview process (Clark, 1999; Clark-lbaNez, 2004; Harper, 1994; Tucker \& Dempsey, 1991).

As these children are active agents in this garden space, I wanted to use this approach as an attempt to balance out the power dynamics between the researcher and the participants. Participant-produced photographs, what Clark (1999) refers to as autodriven photo elicitation, is a step toward that balance. Over the course of the summer, these children captured images of people, plants, animals, or anything that they felt contributed to their garden narrative. Then, as illustrated in Tamika's interview, I asked open-ended questions such as: can you tell me about your picture? Why is that picture important to you?

Throughout the summer, I also took pictures (researcher produced) that documented my role as a gardener, researcher and participant observer in this space. These pictures now serve as a record that reveals the established procedures, values and relationships that these gardeners have with others. Although some researchers take and use their own photographs exclusively during data collection, and others ask participants to take their own photographs, for the purposes of this research, I elected to do both.

Throughout this sixteen-week research project, I spent the first eight weeks directly observing the social interactions of these three elementary-aged gardeners working in the community garden. Their ages range from 7 to 10 years of age, falling within Sobel and Cobb's description of middle childhood. During the second eight weeks, I conducted multiple photo-elicitation interviews (PEIs) with each child. During each of the eight-week periods, these three participants digitally recorded 
their garden experiences on a weekly basis. These digital images became the center of our conversations during the photo-elicitation sessions. As PEls are by nature unstructured, they can last from 30 minutes to several hours. During the first interview, I asked participants to group or organize their photographs in a way that was meaningful to them. In doing so, participants create what Schwartz (1992) calls a "descriptive record" of their experience. Their descriptive record became the structure for the second interview. During the second and subsequent interviews, photographs were used as prompts for children to describe their story, feelings or ideas about the image.

Within the context of the PEI, these children visually and verbally documented relationships that connected them to the subculture of the garden. Pictures, constructed through their camera lens, documented their experiences, their understanding of what it means to be a member of a garden community and a part of the multiple ecological systems that operate within it. Through this visual framing, it is possible to "see" how these children understand themselves as knowers of natural events and as actors within an ecological system. These images and narratives constructed by these children suggest a space for representation similar to that of journal entries, field notes and artifacts, better thought of as "field texts." The visual field texts constructed by the students represent explorations of self and an empathy toward "others" in the garden.

\section{Study Findings}

To initially understand the visual data, I employed Harper's (2002) three categories for photographs used in photo elicitation: Photographs are used as visual inventories; Photographs depict events that reveal institutional forces or organization; Photographs illuminate the social being through their illustrations which connect society, culture and history. Generally, the children's photographs and interviews revealed their day-to-day experiences in the garden. Their personal discourse related to their photographs reflects that of collaborative social practices, experiences and community goals. Their photographs and narratives also reveal their visual paths of exploration and roots of empathy. It is within the intersection of exploration and empathy, rather than the completed stages of ecological identity development as suggested by Sobel or Cobb, that we are able to locate an environmental consciousness or an eco-self. 


\section{Connections Between Place, Exploration, and Empathy}

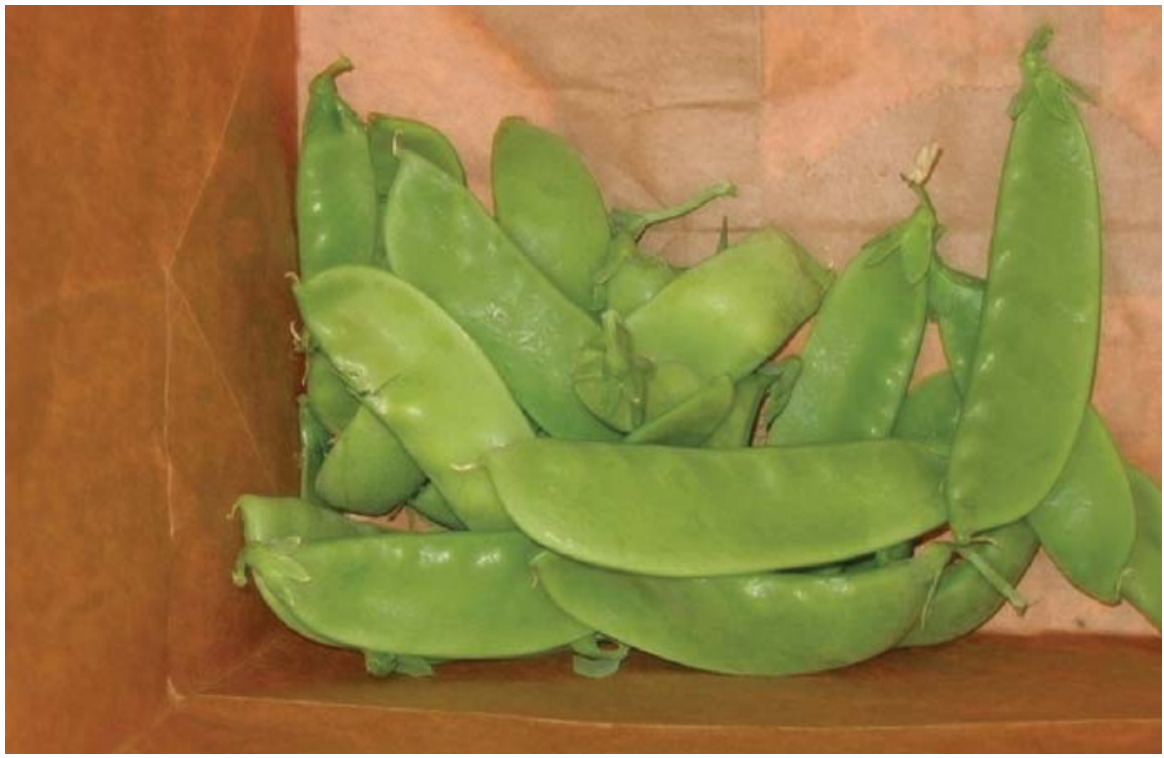

Fig. 5: Peas in the bag

Today we did the vegetable hunt. We had to look for peas and beans that were yellow, black [purple], and green. We had to look for onions and tomatoes and lettuce and yellow squash. And lots of stuff. It was really fun. There was lots of food in the garden store. We put it in bags just like at the food pantry. I got tired of picking though. It was hot.

This picture is about peas. There are three colors of green, light green, a little light green and just green. Some of them have a lot of seeds in them. And some of them are eaten by rabbits. We can look and see how the rabbits teeth are. They only take small bites, but leave marks. Do you see how much the peas were sweating? Just like me during the hunt.

I took this picture because it shows how many of us worked to get all these peas. Everybody was there to help. Like when we planted them, grew them, trained them. Then we had stir-fry. Everybody was eating. You know how we start in the big group, everybody in the garden, like the people from our center and people from the garden we all come up and we all greet each other and get to know each other and stuff. We are all friends now and that's pretty cool. So, I guess I took this cause I really liked it. (Photo elicitation interview, September 8, 2007) 
Tamika's photo of peas in a grocery store bag and her explanation of the vegetable hunt define her exploration of objects found in a garden. However, through her description of the photograph, Tamika describes not only the images of the garden, but also defines these images as representations that have visual meaning and offer a way of understanding how she has recognized her experience and what has influenced her actions and behaviors in this particular place. Within the sociocultural world of the garden, Tamika is safe to explore her role as a member of this group of gardeners. Here, she is able to examine the teeth marks left by a rabbit, an inhabitant of this natural space. Her awareness that she and the rabbit can coexist illustrates her personal beliefs about her role within this local ecosystem. As she relates stories of the life systems surviving within the garden fences, she develops awareness for "other" and empathizes with their condition of being too hot, or in the case of the following narrative, of being unprotected.

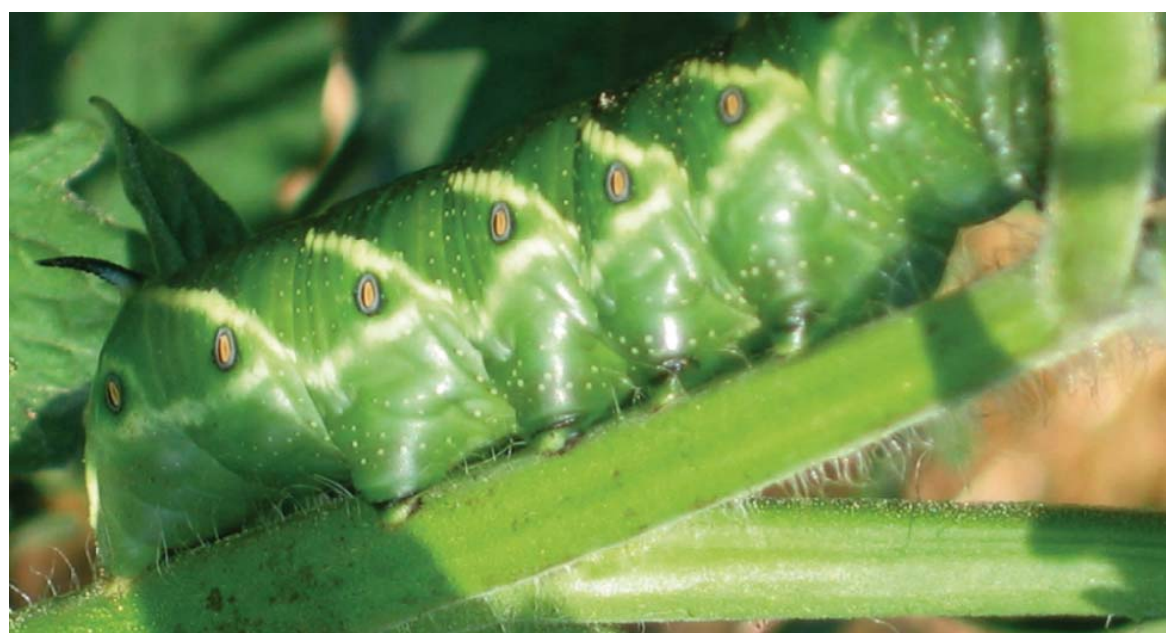

Fig. 6: Tomato worm

This picture is about a cute caterpillar called a tomato worm. I guess it was just walking along on the branch when the boys found it. I was over in the squash when I saw them. They were poking sticks at it. I told them to stop because the caterpillar's teeth were coming out. I could tell it was afraid and mad. I told them to stop before the caterpillar bites you. They said, "ok, I won't do that, I'll leave it alone." And before it ran off I wanted to take a picture of it because they are cute and will turn into a butterfly. Right? I was protecting the caterpillar from the boys so it could grow up. I wanted to take a picture of it when it was a butterfly, but it didn't. I like this picture, cause right now it's just me and the caterpillar looking at each other. It's not showing his teeth, do you see? (Photo elicitation interview, September 17, 2007) 
As the protector of the tomato worm, Tamika's sense that she and the caterpillar belong to this place is revealed both through her photo and her narrative. She frames this experience, not simply in the present, but she also visualizes the future by thinking about taking a picture once this caterpillar has become a butterfly. Again, through exploration into the life of the caterpillar, Tamika is relating to, empathizing with life systems living in the garden. Verbally, she envisions herself almost entering into a familial relationship with this nonhuman creature, while visually depicting an awareness of the social and natural systems supported by this ecosystem.

Like Tamika, Gee also defines his role in the garden. He is a pepper gardener.

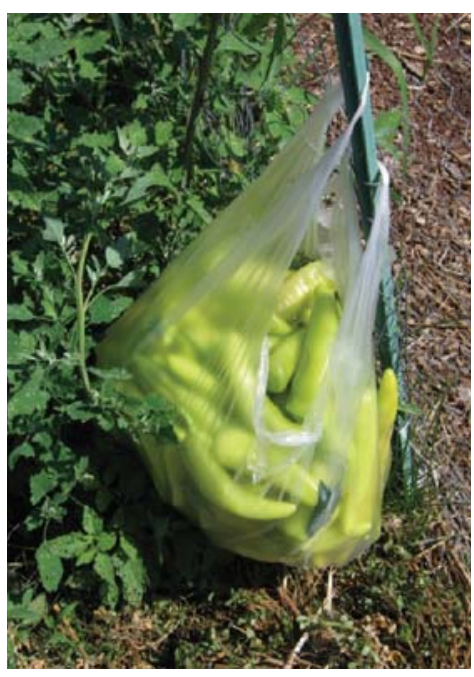

Fig. 7: Photo of the pepper harvest

In the little rectangle garden, we planted some hot green, red and yellowish chili peppers. After a while we put hay on them. That was hard work. Everybody worked together. I liked working with the garden buddies. I liked working with Ruth because she is funny and makes me feel responsible.

What I learned as a pepper gardener is if you touch a pepper with your bare hands and touch your face it feels like a sunburn. And, I did touch them! Me and Tony worked out in the garden. We worked together. When the peppers were ready we were picking them. It is so exciting to see and explore how the peppers looked and how they grew. When they were ready, we picked them. And it was beautiful. (Photo elicitation interview, September 16, 2007)

In this garden environment, Gee is free to explore this world as a pepper gardener. From planting to harvesting, he explores, through numerous images, the history and natural system of the various pepper plants. His exploration of self is eco-centric and community oriented. In fact, both Gee and Tamika express the collective goals of the garden community through their language. They each emphasize the importance of everyone working together, and frequently reference the word "we," indicating their willingness to enter into and maintain their commitment to the group. 


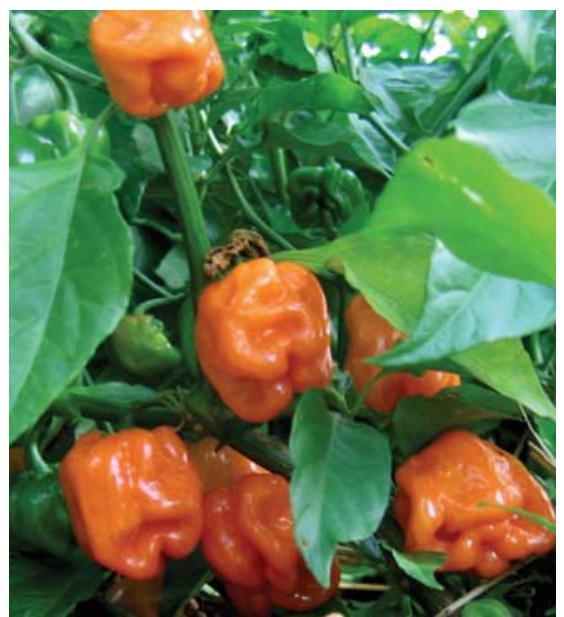

"You can't lie to the earth," stated Gee emphatically one day as he and I looked at a photo of hot peppers he had taken. I looked at him quizzically, not knowing quite how to respond, as the photo was of a habanero pepper plant. "The earth knows when you are lying," he continued, "I might tell you I watered, but the plants know I didn't. And they will tell that I didn't." (Field notes, July 19,2007 )

Fig. 8: Habanero pepper plant

Gee is a nine-year-old working in the community garden and has entered into a dialogic relationship with the earth and the plants living in the garden. By expressing that the plants and the earth know he has told a fib by not watering them, he is empathizing with their thirsty condition. Through empathy, he becomes the earth and the plant, which now have the ability to "tell on" him. Through his photo of a habanero pepper plant, I am able to "see" how Gee understands his relationship with the earth and how he is beginning to develop an eco-identity.

\section{Epilogue}

Shepard contends that mind and body are imprinted by the "pattern of place" experienced in childhood (Shepard, 1996, pp. 93-108). Through the photographs taken by three children within this community garden and through their corresponding narratives, it becomes possible to "see" patterns of experience that reveal: a relationship between human and nonhuman elements of the natural world; empathy and compassion toward the natural world; and that disclose a personal attitude toward the natural environment. Based on their photographs and narratives, I have found changes over time in these three children's assumptions and familiarity with the garden setting. Their early pictures reveal first impressions-landscapes, large or impersonal groups of people, or singular plants. Later pictures reveal greater personal contact with people, an understanding of community garden culture and tradition, intimate portraits of individuals and group events. 
Epistemologically, these photo narratives reveal how these three elementary children have come to know, work and live in their local places. While a community garden appears to outsiders to be a leisurely expression of an individual's time and commitment, a community garden project is the social construction of place and community. Thus, rather than romanticizing this landscape, I argue that we need to critically analyze natured places where we encounter children. I think of playgrounds, parks and gardens, not just as places where children play, but as "spaces that are personally and politically embodied and locally embedded, and are harbingers for new ways of understanding development" (Aitken, 2001, p. 1), particularly the development of the self. These places from which identities can develop are "historically contingent, socially enacted, culturally constructed 'worlds'" (Holland et al., 1998, p. 7). Thus, the world of the community garden illuminates the ideas of sociocultural theory in that "each community garden is rooted in its own unique, complex set of historical, cultural, and structural conditions. Which means it holds its own collectively constructed and shared meanings, interpretations, rituals, and identities for participants-embedded with its own unique narrative" (Glover, 2003, p. 194).

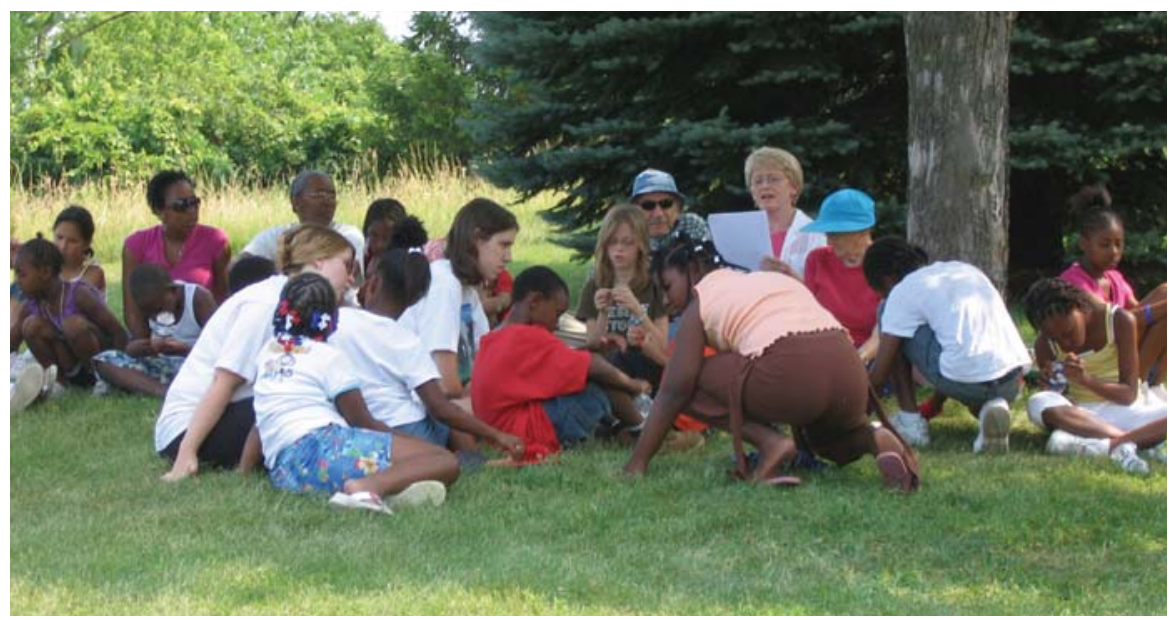

Fig. 9: Sharing ideas under the "welcome tree"

I like it when we are all together. I like it when we sit together and read letters from Africa and do experiments and talk about stuff. (Photo elicitation interview, September 17, 2007)

These two sentences, written in Gee's garden journal, allude to daily rituals that occur within the garden community. Before gardeners pass through the garden gates, we gather under a tree now referred to as the Welcome Tree. Beneath it's shade, we sit in 
a circle for about fifteen minutes telling stories, discussing garden news, and sharing ideas. Following this exchange, garden buddies go into the garden. When our time in the garden is over, we return to the Welcome Tree to eat something we have grown and harvested. We begin and end our morning sitting together in community. Through discourse and interaction, between humans and nature, these dialogic interconnections, "bind garden participants together in a shared experience, which presumably serves to share collective identity" (Glover, 2003, p. 194).

Engaging children as photographers, as researchers, as observers of their natural environment affords them the opportunity to become reflective actors of events within their local communities. This research suggests that those engaged in the research process with children can develop an empowering relationship through the art of photography. The camera, the device that captures the image, fundamentally reveals at base an image. However, that image "is invaded by language when it is looked at: in memory, in association, snatches of words and images continually intermingle and exchange one for the other" (Burgin, 1982, p. 192). This shaping of text, this "intermingling" of words and image, transforms a static photograph into one that, through language, is both dynamic and reflective.

\section{References}

Aitken, S. (2001). Geographies of young people. London: Routledge.

Bakhtin, M. (1981). The dialogic imagination: Four essays by M. M. Bakhtin. (M. Holquist \& C. Emerson, Trans.). Austin: University of Texas Press.

Burgin, V. (1982). Thinking photography. London: Macmillan.

Clark, C. D. (1999). The autodriven interview: A photographic viewfinder into children's experiences. Visual Sociology, 14, 39-50.

Clark-lbanez, M. (2004). Lessons in inequality: A comparative study of two urban schools. Dissertation Abstracts International A: The Humanities and Social Sciences, 64(7), 2650A.

Cobb, E. (1977). The ecology of imagination in childhood. Dallas: Spring Publications.

Collier, M. (2001). Approaches to analysis in visual anthropology. In Leeuwen, T. \&
Jewitt, C. (Ed.), Handbook of Visual Analysis (pp. 35-60). London: Sage.

Glover, T. (2003). The story of the queen anne memorial garden: Resisting a dominant cultural narrative. Journal of Leisure Research, 35(2), 190-211.

Gruenewald, D. A. (2003). The best of both worlds: A critical pedagogy of place. Educational Researcher, 32(4), 3-12.

Gruenewald, D. A. (2005). More than one profound truth: Making sense of divergent criticalities. Educational Studies, 37(2), 206-215.

Haas, T., \& Nachtigal, P. (1998). Place Value: An educators guide to good literature on rural lifeways, environments and purposes of education. Charleston WV: ERIC.

Harper, D. (1994). On the authority of the image. In Denzin \& Lincoln (Ed.), Handbook of Qualitative Research (pp. 403-412). Thousand Oaks, CA: Sage. 
Holland, D., Lachicotte, J.W., Skinner, D., \& Cain, C. (1998). Identity and agency in cultural worlds. Cambridge: Harvard University Press.

Louv, R. (2005). The last child in the wilderness. Chapel Hill: Algonquin Books.

Norman,W.R. (1991). Photography as a Research Tool. Visual Anthropology, 4, 193-216.

Orr, D. W. (1992). Ecological literacy: education and the transition to a postmodern world. Albany: SUNY Press.

Prosser, J. (1998). Image-based research. London: Falmer Press.

Schwartz, D. (1992). Wacoma twilight: Generations on the farm. Washington, DC: Smithsonian Press.

Shepard, P. (1986). Introduction. In E. Cobb, The ecology of imagination in childhood. Tokyo: Shishaku-sha Publications.

Shepard, P. (1996). Traces of an omnivore. Washington: Island Press.

Sobel, D. (1996). Beyond Ecophobia: Reclaiming the heart of nature education (Vol. 1). Great Barrington, MA:The Orion Society.
Sobel, D. (2008). Childhood and Nature: Design principles for educators. Portland, ME: Stenhouse Publishers.

Taylor, E. (2002). Using still photography in making meaning of adult educators' teaching beliefs. Studies in the Education of Adults, 34(2).

Theobald, P. (1997). Teaching the commons: Place, pride and renewal of community. Boulder, CO:Westview.

Thomashow, M. (1996). Ecological identity: Becoming a reflective environmentalist. Cambridge: MIT Press.

Tucker, S. A., \& Dempsey, J.V. (1991). Photo-interviewing. Evaluation Review, 15(5), 630-653.

Vygotsky, L. S. (1978). Mind in society: The development of higher psychological process. Cambridge, MA: Harvard University Press.

Weade, R., \& Ernst, G. (1990). Pictures of life in classrooms, and the search for metaphors to frame them. Theory to Practice, 29, 133-140.

Ziller, R. C. (1990). Photographing the self. London: Sage.

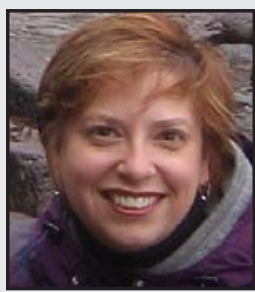

Ann Grugel is a doctoral student in the Department of Curriculum and Instruction at the University of Wisconsin Madison. She is a former teacher of high school English, journalism, psychology and American studies. Her current research involves exploring the intersections between environmental literacy, eco-justice, and eco-identity development in elementary-aged children. 